\title{
The Nexus between Teaching Practice and PGCE Student-Teachers: The Perceptions of Subject Mentors on Pre-Teachers' Readiness for Teaching Career
}

\author{
Rachel Gugu Mkhasibe ${ }^{1}$, Dumisani Wilfred Mncube ${ }^{2}$, Oluwatoyin Ayodele Ajani ${ }^{2, *}$ \\ ${ }^{1}$ Education Professional Practice, University of Zululand, South Africa \\ ${ }^{2}$ Department of Social Science Education, University of Zululand, South Africa
}

Received March 16, 2021; Revised April 16, 2021; Accepted June 6, 2021

\section{Cite This Paper in the following Citation Styles}

(a): [1] Rachel Gugu Mkhasibe, Dumisani Wilfred Mncube, Oluwatoyin Ayodele Ajani, "The Nexus between Teaching Practice and PGCE Student-Teachers: The Perceptions of Subject Mentors on Pre-Teachers' Readiness for Teaching Career," Universal Journal of Educational Research, Vol. 9, No. 9, pp. 1617 - 1627, 2021. DOI: 10.13189/ ujer.2021.090902.

(b): Rachel Gugu Mkhasibe, Dumisani Wilfred Mncube, Oluwatoyin Ayodele Ajani (2021). The Nexus between Teaching Practice and PGCE Student-Teachers: The Perceptions of Subject Mentors on Pre-Teachers' Readiness for Teaching Career. Universal Journal of Educational Research, 9(9), 1617 - 1627. DOI: 10.13189/ujer.2021.090902.

Copyright $\mathrm{O} 2021$ by authors, all rights reserved. Authors agree that this article remains permanently open access under the terms of the Creative Commons Attribution License 4.0 International License

\begin{abstract}
Teaching practice is critical to teacher education as it provides the pre-service teachers with practical experience of professional responsibilities and classroom practices, which are basic foundations for their choice of teaching as a profession or career. It is mandatory for pre-service teachers to experience teaching practice as a requirement in teacher education to acquire practical teaching competence in schools. Students in teaching practice are required to be mentored by their subject teachers in the schools. Thus this study investigates subject mentors' perceptions of Post Graduate Certificate in Education (PGCE) students' teaching practice lived experiences to determine their readiness for professional classroom practices. Competence and readiness to teach are inseparable because the latter demonstrates the skills which pre-service teachers display when delivering certain aspects of their teaching. Hence teaching is incomplete without teaching practice. Five subject mentors who were mentoring PGCE student teachers were purposively selected and engaged in semi-structured interviews for the data collection for this study. Content analysis was used to identify themes and analyse the data. The findings revealed, among others, that PGCE student teachers do not have adequate pedagogical content knowledge. Based on the findings, the study, therefore, recommends that the training for PGCE students has to be increased from one year to two years to acquire the appropriate knowledge and skills.
\end{abstract}

Keywords Mentors, Perceptions, Student Teachers, Teaching Practice, PGCE

\section{Introduction}

Teaching is a dignified profession that requires a combination of passion and pedagogical training to be able to make a difference in the lives of the children and adolescents who constitute the bulk of learners in primary and secondary schools. The opportunity to contribute to their academic and social development is one of the priceless noble goals that every classroom teacher aspires to achieve.

However, it is widely believed that the training of pre-service teachers is not complete without their being exposed to the work-integrated learning (WIL) aspect of the pre-service teacher training programme generally known as "teaching practice" [20], [25], [27]. In a pre-service teacher training programme, like many other professional programmes, teaching practice is required, and mandatory for all students who want to do a teaching qualification. Teaching practice is expected to complement the theory that pre-service teachers acquire in their institutions, and pre-service teachers are therefore expected 
to put into practice the theory which they have obtained in their institutions.

Although most researchers have explored pre-service teachers' readiness to teach, there are very few studies that have focused on PGCE students. PGCE students have a different programme from B.Ed students, spending a year in acquiring pedagogical content knowledge and WIL simultaneously. This programme is intense and comprehensive, to obviate students' complacency and error. The Teaching Practice Unit is required to monitor this cohort closely in working with schools to achieve competent graduates. Considering the limited time and nature of the programme, it would be interesting to understand teachers' readiness to teach. Thus, the study explored the preparedness of PGCE students to teach, taking into consideration the teaching practice experience the higher education institutions provided them with, within the given one year of preparation as teachers.

Different higher education institutions (HEIs) have different models of conducting a PGCE programme [36]. It is mentioned above that at the institution where this study was conducted, it is a one-year programme for those students who hold a relevant undergraduate degree or an approved diploma. These students should have sufficient disciplinary learning in the appropriate academic field to enable the development of teaching specialisation phases or subjects as specified for each phase. Students are admitted to the programme at the beginning of each calendar year. The PGCE programme is delivered on a full-time basis, with face-to-face contact. Work-integrated learning takes place on campus (in the microteaching lab), while the other practicals take place in surrounding schools. The purpose of the qualification is to prepare these students with pedagogical content knowledge and practical experience both on-campus and in schools. The programme is very strong in practical skills, also known as work-based experience that pre-service teachers will apply in schools in varying contexts. This programme is premised on fulfilling the following aims so that a candidate is certified with the PGCE qualification:

- development of subject-specific teaching
competence;

- development of effective values and practices that enable the teacher to function under diverse conditions with various types of learners;

- development of competence to critically reflect on teaching and learning experiences to self-enrich.

These important aims have to be met to render the programme accredited by the Department of Higher Education and Training (DHET). Concern, though, has arisen because of the limited exposure of one year, and the question worth asking is: "To what extent are these students competent to deliver expected outcomes?" Despite the comprehensive nature of the PGCE programme to produce highly qualified students, many scholars question the PGCE students' readiness to teach upon receiving the PGCE qualification. Their doubts and fears were interrogated during this investigation to determine whether or not a one-year qualification is enough to prepare students to teach.

The PGCE students are placed in local partner schools to do their teaching practice every Wednesday in the first semester. During this period they are assigned to teachers who will mentor them throughout the teaching practice. Later in the second semester, they return to their respective schools to do teaching practice for six weeks. In this period, they are expected to work closely with school subject mentors, while university supervisors monitor and support their progress by visiting them twice and evaluating them on a third visit. The university supervisors must hold a mini-conference with both the subject mentors and the PGCE students before and after the lesson observations. The main purpose of holding these mini-conferences is to support the students about fundamental expectations during observation when teaching. On their third visitation, the university supervisors finally evaluate the students to determine whether or not they are ready to teach. However, their subject mentors too have a right to evaluate them before they are evaluated by their university supervisors.

Hence, the main aim of this study is to explore the role of subject mentors in preparation of PGCE students during teaching practice. Conversely, answers to the research question - What are the role of subject mentors in pre-service PGCE teachers' experience to prepare them for the profession during teaching practice, were provided through the semi-structured interviews with selected subject mentors.

\section{Theoretical Framework}

Teaching practice experience is not only mandatory as part of the requirements for obtaining a Bachelor of Education and Post Graduate Certificate in Education (PGCE). It critically lays foundations for pre-service teachers in the pedagogy of professional classroom practices in South African universities. Pre-service teachers' readiness to teach is a continuous process that continues even after their formal education at the universities. [18] opine that teaching is complex, and requires life-long learning for the pre-service teachers, where several opportunities are presented to them to learn and connect both theories and pedagogies in teaching with the support of experiences from communities of practice. Seemingly, [16] assert that subject-mentors play critical roles in bridging the gap between teaching theories and practical for pre-service teachers. The students learn from their subject teachers who serve as mentors to them. They lay foundations for their teaching experiences based on observations, interactions and delegation of responsibilities in the field experiences.

Hence, experiential learning theory as adopted in this 
study enhances their readiness for a career in teaching. The rationale for experiential learning theory is its focus on reflection and active participation of pre-service teachers in school system activities through experiential learning. According to [15:131], "Rooted in the work of Dewey, Piaget, Vygotsky and Hahn, experiential learning is an overarching term used to classify several different forms of learning approaches, including problem and inquiry-based learning. Yet at the centre of each is a focus on a lived experience upon which learners can reflect, think and act".

Experiential learning theory was proposed by David Kolb as influenced by the great works of John Dewey, Jean Piaget and Kurt Lewin. According to [22], learning is best facilitated as a systematic process of transforming experience. This implies that knowledge by pre-service teachers can result from their lived experiences from teaching practice experiences to transit into professional classroom practices. Experiential learning describes learning as a process from action, practice, observation, discovery and exploration of opportunities. Pre-service teachers are key elements of experiential learning theory, and their involvement in teaching practice enables their lived experiences and participation to enrich them with necessary pedagogical approaches to classroom practices.

According to [22], experiential learning's focus on pre-service teachers' teaching practice is a process that:

- enables pre-service teachers in direct and active activities or interactions with stakeholders in the school system. The students can observe, feel, hear, smell, taste, and intuit to reflect actions.

- brings them to realities that are different from theories they learn from textbooks as the central for knowledge production.

- engages the students in continuous learning between schools' immediate experiences and their own personal reflections to construct or reconstruct previously taught beliefs to influence their future experiences and behaviour [12].

- enhances the transformation of lived experience into new knowledge for action [22].

The process is illustrated in the diagram below:

\section{Experiential

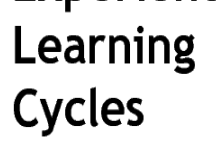

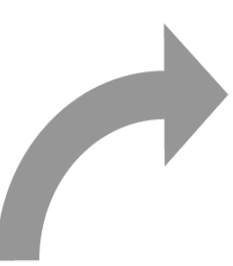
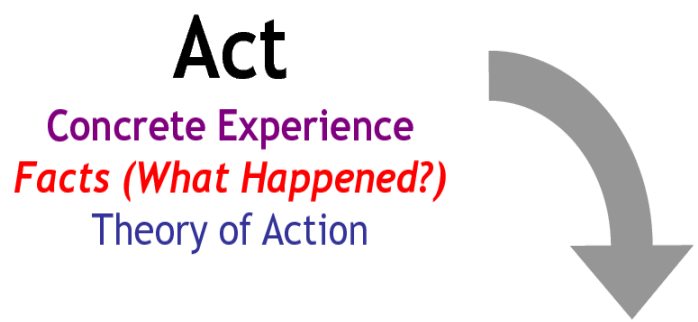

Apply

Active Experimentation Futures (What Will I Do?) Implement Revised Theory

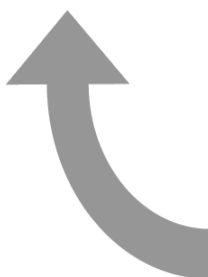

1. David Kolb

Conceptualize Abstract Conceptualization Findings (Why Did This Happen?)

Reflect

Reflective Observation

Feelings (What Did I Experience?)

Assess Behavior \& Consequences

Revise Theory

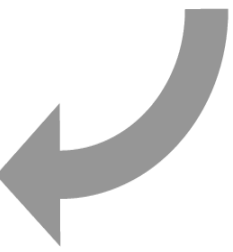

Figure 1. Experiential learning theory cycle (Adopted from [14]). 
This study, therefore, adopts experiential learning theory for effective mentoring and professional integration of pre-service teachers into the teaching profession for professionalism. Subject mentors' goal is to support student-teachers with necessary opportunities that can promote effective and professional classroom practices of their mentees, who have taken them as role models. The student-teachers learn a lot from the schools, the communities, their subject- teachers, school leadership skills and learners to act responsibly and multi-tasks successfully in the school system. According to [3], experiential learning places much emphasis on concrete experiences that pre-service teachers can apply to professional classroom practices, emanating from their participation and experiences from teaching practice. The observations of their subject-teachers, who as mentors equip them with problem-solving skills in the school system, in readiness for the teaching profession. These observations enhance critical thinking, in-depth understanding and diverse perceptions for the abstract conceptualization of new knowledge. Thus, experiential learning as described by [22], drives pre-service teachers' reflection of their teaching practices on their readiness for professional classroom practices. During the teaching practice, opportunities should be provided by the subject-teachers to mentor pre-service teachers' reflection. This will enable them to connect the actual and real experience with the knowledge-based experience. Conversely, the experiential learning theory is situated within the reflective observation of concrete lived experiences and active experimentation of new knowledge based on abstract conceptualizations [3].

\section{Literature Review}

\subsection{Concept of Teaching Practice}

The concept of teaching practice is described as a process that exposes and empowers student teachers in teacher education to practical complexities and richness of classroom practices and the teaching profession as a career [4], [14], [17], [39]. This process allows student-teachers to experience the reality of the school system as they make choice as career-teachers. Their lived experiences during teaching practice provide them with first-hand information that can make or mar their decision to be professional teachers and also change agents. Kuggundu and Nayimuli (2009) aver that teaching practice is an intense programme in teacher education where the ugly experience of teaching practice can demoralise and frighten student-teachers in the profession. However, [17] assert that teaching practice equips pre-service teachers with diverse opportunities to gain an in-depth understanding of both the professional teaching practice and personal practical experience or reality of the profession. Seemingly, [25] affirms that the need for a practice-oriented approach as well as the acquisition of professional skills before assuming a teaching career drives teaching practice. Indeed, it exposes pre-service teachers to the classroom situations [21]. Meanwhile, [6] highlights that teaching practice equips pre-service teachers to teach in diverse classroom contexts, and apply the theories of content knowledge, skills, and professional dispositions they have learned in the university-based modules in classroom practice to classroom realities during the teaching practice.

[32:41] point out that "teaching practice enables pre-service teachers to be ready for the assumption of duty as professionals who are motivated, conscientious for efficient classroom practices while encouraging the spirit of inquiry, creativity and intellectual development in their learners as beneficiaries of the educational system." [31] in their submission posit that teaching practice is a platform that can enable the student-teachers to maximize necessary knowledge, skills and competences to contribute to national economic and social development. There are various teaching practice models available to different teacher training institutions depending on the Minimum Requirement for Teacher Qualification (MRTEQ) (The Department of Higher Education and Training, [29], [30]. At the University of Zululand, a student teacher is required to do teaching practice in at least two different schools.

Reference [25] asserts that teacher training must address fundamental knowledge about inclusive education. In this regard, sufficient skills in identifying barriers to learning are prioritised, as well as in curriculum differentiation to address the needs of individual learners in the education system [11]. It is evident from the above definitions that the teaching practice experiences are meant to support pre-service teachers with adequate practices for the construction of practical knowledge and learning. [14] avows that teaching practice is a compulsory experience or practice in most teacher educational institutions worldwide. Suffice it to say that there can be no effective teachers if there is no teaching practice.

\subsection{Subject Mentors' Expectations from Pre-Service Teachers}

In the teaching profession context, mentoring facilitates the training and development of newly qualified teachers and pre-service teachers in learning how to teach. They learn from experienced and seasoned teachers who are called subject mentors [29]. For the mentoring process to run smoothly, both the mentors and the mentees have to establish a good reciprocal relationship. This means that both the subject mentors and pre-service teachers have expectations from one another. For instance, subject mentors expect the pre-service teachers who are placed under their supervision, as mentees to be willing to learn. This, [38] affirm that pre-service teachers must be 
"mentorability". This implies the readiness of the mentees to be guided by subject mentors, by showing characteristics such as initiative, learning orientation, goal orientation, relational skills and reflectiveness. This means that pre-service teachers should not go to schools for teaching practice as "tabulae rasae". They participate in teaching practice to integrate the theory they have obtained from their higher education institutions with the practice they obtain from schools. The practical experience is obtained with the assistance of their subject mentors. Pre-service teachers are to be mentored by subject mentors who have all the required teaching competences and experiences. However, this may be difficult to attain if some of these PGCE students are not prepared to learn or simply not goal-oriented. The subject mentors may not be able to instil those characteristics without pre-teachers' readiness and willingness to cooperate. [27] avers that some PGCE students resort to the teaching profession because they think they can be easily employed in the education system. This implies that some of them pursue the teaching profession after failing to get employment for their desired primary careers. So, to them, teaching is a springboard or waiting-room for a n other career. H e n c e, it becomes difficult for subject mentors to make an impact on such mentees.

In addition to the above-mentioned expectations from subject mentors, the mentors themselves are expected to work closely with the pre-service teachers during the entire period of school teaching practice, this is to provide closely guided mentorship during the duration of the teaching practice. This includes exposing them to effective use of CAPS documents in teaching and assessment, crafting lesson plans, administration of different forms of assessment, conducting themselves professionally to the learners, and participating in extra-mural activities in the school system.

\subsection{Mentoring Process to Support Student Teachers}

For the PGCE programme to run smoothly, the HEIs are expected to establish a good partnership with the schools the pre-teachers can do their teaching practice. [7] assert that the partnership is based on goodwill and relationships built up over time between universities and school staff for acceptance of pre-service teachers for teaching practice. [36] posit that the success of the PGCE programme depends on the quality of the relationship between universities where the programme is offered and the schools where the PGCE students are mentored to acquire the relevant competencies for the teaching profession, self-direction of learning and professionalism. [36] stress that even though learning to teach for PGCE students is complex, it becomes manageable if the student teachers receive good guidance and support from their subject mentors, as well as all other school stakeholders. [19:1] remark that "mentoring programmes have beneficial effects on job satisfaction, career success, personal development, reflection and self-direction of learning."

The PGCE students have to grasp this opportunity of being mentored with both hands because they get the opportunity of observing their subject mentors' teaching, for them to learn how pedagogical content knowledge (PCK) is applied, and how classrooms are managed for effective teaching and learning [28]. According to [35], there are four types of activities that subject mentors are expected to focus on while mentoring PGCE students. These activities are:

- Learner-centred activities: these aim at acquainting PGCE students with the thinking and behavioural patterns of diverse learners and their motives for learning.

- Knowledge-centred activities: these specify what PGCE students have to learn as skills in planning long-term learning goals and formulating objectives for lessons to be taught.

- Class-centred activities: these focus on cooperative learning and the creation of a social atmosphere suitable for all learners, irrespective of their learning barriers.

- Activities on the evaluation of learners: these focus on how learners are evaluated after they have been taught by PGCE students. They help the pre-service teachers to determine different forms of assessment that can be used to assess teaching and learning.

Mentoring of pre-service teachers by the subject teachers during teaching practic, provides a significant opportunity to these novice teachers to learn in-depth about operating school policies, procedures and regulations, as well as sharing teaching methods, learning and teaching support materials, and other professional resources that can serve as support to their professionalism in the school system [30], [34], [37]. Reference [18] opine that teaching practice experience provides real experiences to pre-service teachers where the experienced teachers mentor them on what is required in teaching and learning, the professionalism of teachers and documents to work with. Reference [16] agree with [22] that experience from sharing teaching methods, learning materials and other useful resources with the pre-service teachers during the teaching practice are critical ways of mentoring pre-service teachers to solve teaching and learning problems, as well as providing them with personal skills and professional support that can guide their entrance and growth in the profession.

Reference [7] highlight the following as four models of mentoring:

- Zero levels: which focus on valuable interpersonal skills, but make no use of the skills which the teacher has as a teacher.

- Minimal mentoring: which involves the supervision of pre-service teachers in their planning and implementation of lessons. 
- Developed mentoring: which deals with collaborative teaching, and allows pre-service teachers to access experienced teachers' craft knowledge. This model also provides a context for the discussion of the ideas behind teaching practice.

- Extended mentoring, which occurs when a pre-service teacher has achieved basic competence as a teacher, and can also be regarded as the equal partner of the subject mentor. This model may go to the extent of providing pre-service teachers with access to expertise on a range of whole school issues.

The above responsibilities are also highlighted by [35] to show explicitly why the subject mentors are role players in the development of PGCE students. The pre-service teachers spend most of their mentors in the real situation of the profession. However, it becomes a challenge if the PGCE students are mentored by teachers who possess neither the required competencies of a teacher nor a passion or at least willingness to mentor pre-service teachers. Consequently, the PGCE students end up gaining nothing from teaching practice, because teaching practice is where pre-service teachers get the opportunity to integrate theory and practice. Moreover, that integration has to take place under the supervision and guidance of competent subject mentors.

In England and Wales, for instance, their initial teacher education depends upon a legal and contractual partnership between schools and higher education institutions. Moreover, their subject mentors are often trained to support pre-service teachers' development [7]. This commitment between schools and higher education institutions in England and Wales, as well as the training of subject mentors, plays a significant role by encouraging the subject mentors to effectively mentor pre-service teachers during the teaching practice in their schools. Secondly, the pre-service teachers receive the best mentoring because all their subject mentors receive adequate and regular training from the HEIs on how to mentor pre-service teachers.

\section{Research Design and Methodology}

The study is underpinned by a qualitative explanatory case study of five subject mentors who were assigned to work closely with PGCE students during a teaching practice exercise in their schools. The interpretivist paradigm enabled the researchers to focus on describing how people make sense of their own worlds, and how they make meaning of their actions [8]. This qualitative case study was important to the study as it allowed the study to be more expressive, explorative in its design and purposive to generate a rich in-depth description of explored phenomena [9], [10].

Sampling is the process of making a decision about which people, setting, events or behaviours to observe or study [9]. The researchers purposively selected five subject mentors from five high schools in the uMkhanyakude district where PGCE students had their teaching practice. Convenience sampling was then utilized to choose only five of the subject mentors who possessed the required attributes and experience needed to mentor student teachers. Subject mentors are regarded as experienced and highly knowledgeable in the teaching profession, and pre-service teachers spend most of their time under their supervision in schools.

The selected subject mentors were the most accessible and had the experience of more than five years in their schools. An ethical clearance to conduct the study was obtained from the concerned university, while all other ethical considerations of confidentiality, voluntary participation, informed consent and anonymous reporting were all strictly adhered to while all the necessary approvals were obtained from the school authorities [10].

Semi-structured interviews were conducted at sampled schools, at the convenience of the participants without interfering with the teaching and learning activities of the schools. All the interviews were audio-recoded with the permission of the participants. Ten university supervisors' documents that were used for the evaluation of the PGCE students were also used in data collection. University supervisors are the lecturers who teach theory to the pre-service teachers in their institutions of higher learning. They are also responsible for the final evaluation of PGCE students in schools during teaching practice.

Content analysis was used to identify themes and analyse the data. The audio-recorded interviews were transcribed and were given to the participants to confirm their responses; the transcripts were later coded to generate themes for presentation and discussion of findings [5]. The themes from the semi-structured interviews and document analysis of the university's evaluation documents were compared, synthesised and interpretively presented as themes. The subject mentors were coded as SM1-SM5; that is, SM1 for subject mentor one and SM2 for subject mentor 2 up to mentor 5 in excerpts. The transferability, dependability, conformability and credibility to confirm the trustworthiness of the findings were ensured [9].

\section{Findings and Discussions}

\subsection{Findings}

The responses from the participants provided answers to the research questions. The subject mentors expressed their experiences concerning their engagement with PGCE student teachers over the past six months. Thus, they provided an in-depth understanding of their perceptions of experienced subject mentors about the readiness of the PGCE pre-service teachers. Their views as freely shared with the researchers generated the following themes: 


\subsubsection{Exhibition of professionalism}

The responses from the interviews with the subject mentors concurred with the documents of the university supervisors. They both mentioned that the PGCE students understood and kept up with school policies, timetables, and the vision and mission statements of the schools. Their attitude towards the profession was good. For instance, they did not have to be reminded to attend to their classes: greeting their learners when entering the classroom, acknowledging their mistakes when they were corrected by learners, calling learners by their names, and praising them when they responded appropriately. These they expressed:

SM1: "They always observe and honour their teaching slots, and we never reminded them."

SM2: "We do not have a problem with their dress code. They always look presentable for the profession."

SM4: "They do show a professional attitude to the learners, and the learners enjoy their presence."

\subsubsection{Application of pedagogical content knowledge}

Of the five subject mentors who were interviewed, only one mentioned that the PGCE students applied pedagogical content knowledge appropriately. However, the majority concurred with the documents of the university supervisors. They stated that most PGCE students use only the telling method of teaching. The subject mentors concurred with the documents by saying:

SM2: "I was so happy when the PGCE students were assigned to me, and I got the shock of my life when they were given a chance to teach. I was thinking that they would excel because of the content knowledge of the subject which they acquired while they were doing their junior degree."

SM5: Even in languages, most of the PGCE students do not have content knowledge. For instance, they cannot differentiate among how to teach creative writing, grammar, language, literature and orals. With them, they cannot tell. It becomes a challenge because every week they have to teach all these aspects."

\subsubsection{Communication skills}

The PGCE students were expected to demonstrate effective verbal and non-verbal techniques to foster active inquiry, collaboration and supportive interaction in the classroom. The subject mentors' responses corroborated the document analysis. For instance, two of them mentioned that the majority of PGCE students preferred to use verbal techniques rather than non-verbal techniques, such as using the chalkboard. These they had to say:

SM2: "They rarely used a chalkboard and they just read the book as if they were reading the literature, and kept on code-switching when explaining something to the learners."

SM5: "Most of the PGCE students did not hesitate to use a finger to erase, instead of using a duster when they realized that they had written something wrong on the board. Moreover, their chalkboard summary was not flowing."

The responses of the subject mentors denote that the PGCE students have a challenge in imparting knowledge using the medium of instruction, which is English. This implies that initial teacher education preparation does not adequately prepare graduates for real teaching using English as a medium of instructions. What is also surprising is that all the university supervisors' comments about the PGCEs' communication skills stated that they were good.

\subsubsection{Writing the summary of the lesson on a chalkboard}

What was noticed by the researchers is that the responses of the subject mentors were not altogether incongruent with those of the documents of the university supervisors. The documents stated that most of the PGCE students did not have adequate competence in chalkboard summary writing. For instance, they did not divide the board and that caused them to write wherever they felt like writing. This made their summary illogical. However, one of the interviewed subject mentors responded like this:

SM2: "Writing on the board is clear, and they use a duster and a ruler to divide the board."

SM5: "They use the chalkboards to write but they still need to improve on the adequate and effective use of chalkboard in their teaching".

SM3: "At first, they find it difficult to use the chalkboard professionally. They prefer to talk. But with corrections, they were improving on the use of the chalkboard".

\subsubsection{Learning teaching and support materials (LTSM)}

The university documents stated that most of the PGCE students relied solely on the textbooks and the charts. Additionally, their charts were not properly drawn and were also congested. University supervisors also commented on the inadequacy of the charts and their irrelevance to the lessons taught. However, four of the interviewed subject mentors were appreciative of how the PGCE students used LTSM. The following are some of their responses:

SM3: "Textbooks are not sufficient; otherwise they know how to use teaching and learning support materials."

SM4: "Our school does not have sufficient learning, teaching and support material, and even with the board it is not easy to see what is written on it."

Only one subject mentor concurred with the university supervisors' documents. Here is his response:

SM2: "They use textbooks most of the time as their teaching and learning support materials."

\subsubsection{Classroom management}

The university's documents stated that the learners of the schools which were visited were behaving very well. However, most of the PGCE students were not confident in 
their teaching. For instance, they did not discourage learners who were responding simultaneously to the questions asked. They also mentioned that other learners became so excited to answer questions during lessons. They kept on calling the teacher when they wanted to respond to the questions. The interviewed subject mentors reported as follows:

SM1: "Classroom management is fine. Some learners like to disrupt them when they are teaching, but they manage to control them. They can create a positive learning space."

SM2: "Yes. Like the arrangement of desks, they make sure that all learners see what is written on the board."

The other two subject mentors concurred with the university supervisors' documents when they pronounced that PGCE students were shy in most cases when the learners were disrupting their lessons. They reported as follows:

SM3: "The pre-service teachers' voices should be audible to drive the lesson forward. That is the challenge which they have, and that causes the learners to disrupt their classes."

SM5: "He used to write the names of the learners who disturb him in class, and submit the list to me."

\subsubsection{Commitment to learn}

The interviewed subject mentors revealed that all the PGCE students show maturity because they have a desire to learn, but the only problem with them is that they always like to stay together as students. Here are two of their responses:

SM3: "They desire to change for the better, to be the best teachers when they exit the programme."

SM1: "Grooming and deportment are good, but they isolate themselves".

\subsection{Discussion}

This study aimed to investigate the subject mentors' perception of PGCE students' readiness to teach. The findings revealed that pre-service teachers displayed professionalism during the teaching practice. This concurs with [22] that exposure to appropriate learning experience provides pre-service teachers with the necessary knowledge and skills that make them fit for teaching responsibilities. The pre-service teachers were reported by the mentors to have possessed the right attitude to work. According to the findings, they looked presentable and treated their learners and all other stakeholders of the schools with dignity and respect. They were highly motivated; displayed sound morals, and had a good relationship with learners, their colleagues, parents and their employer. These responses imply that $\mathrm{t} h \mathrm{e}$ teacher education programme place much emphasis on the importance of professionalism to pre-service teachers when they were about to go for teaching practice [33], [27],
[37]. For instance, dressing appropriately and how they act are as important as what they have to teach. They have an idea of how they are expected to behave in the teaching profession. This increases their chances of employment. [16] assert that the teaching profession requires professionalism, which entails possession of appropriate knowledge and skills, good communication skills and robust relationships with all stakeholders in the system. This is why [3] affirm that regular training should be provided to support teachers on regular basis to ensure smooth teaching and learning. [15] describe mentoring of the novice and new entrants into the profession by the experienced teachers as a critical and quick approach to blend the pre-service teachers.

Findings from the participants and the university's supervisors' documents attest to the significance of pedagogical content knowledge in pre-teachers. It was evident from supervisors' documents that some pre-service teachers' disposition of pedagogical content knowledge during the teaching practice did not encourage learners' development of critical thinking, problem-solving and performance skills because the teaching becomes teacher-centred instead of learner-centred. The promotion of effective learning in learners is significantly influenced by learner-centred teaching approaches [2], [3], [28], [30]. Moreover, they did not have adequate content knowledge. They were transmitting deficient knowledge to their learners. Rephrasing of questions was also a challenge to most of the pre-service teachers. They were not giving learners a chance to think about how to respond to the questions asked [31]. They kept on asking the very same question without rephrasing it. The pre-service teachers' inadequacy in applying pedagogical content knowledge for example, not knowing how to use different representations of the concepts, failing to allow learners to understand the concepts by teaching in the best way - is a serious challenge [21]. It denotes that both teacher education programmes and teaching practice need to put more emphasis on pedagogical content knowledge when training pre-service teachers [22]. [17] assert that if both teacher education and teaching practice programmes do not focus on training pre-service teachers appropriately, that can have a damaging effect on the life of learners and of the society at large.

Reference [14] avows that teachers need to be highly competent in the following areas to excel in their profession: listening, speaking, reading and writing. Senior teachers kept demonstrating that pre-service teachers have a language barrier. Their predominantly verbal teaching method favoured auditory learners at the expense of the visual learners. As a result, it did not cater to learners' multiple intelligences. [37] argues that pre-service teachers should be aware that effective non-verbal techniques foster active inquiry, collaboration and supportive interaction in the classroom. Ineffective use of chalkboards denotes that the PGCE students did not give themselves 
enough time to go to the chalkboard room and practise how to write on the board. [30] affirm that teachers' use of the board is critical to lesson delivery especially in schools where modern technologies have not been fully integrated.

We are living in the Fourth Industrial Revolution, but none of the PGCE students made use of any technology as LTSM [34]. According to [28], learning and teaching support materials are key strategies of delivery curriculum effectively. Findings revealed that pre-service teachers are not conversant with how to use a variety of learning and teaching materials. This denotes that both lecturers and subject mentors do not pay much attention to how pre-service teachers use LTS Ms, including creating charts as well as making use of them when teaching.

Classroom management is a key aspect of effective teaching and learning. This assertion is supported by [23], [24], who postulate that classroom management is the central element of every teacher's daily professional experience. The findings of this theme show that pre-service teachers are unable to manage their classes. This denotes that pre-service teachers are not provided with a proper orientation before going on a teaching practice exercise [22]. They are also not exposed to microteaching to make them gain enough confidence during the real exercise of teaching in schools. Both lecturers and cooperating teachers should work very hard to help the PGCE students to be able to manage their classes because if the class is unconducive, no teaching can take place. [38] mention three constructs that pre-service teachers have to use when they enter the teaching profession. They are experience, empathy, and desire to change.

\section{Conclusions}

Subject -mentors revealed different perceptions on the readiness of pre-service teachers to teach as displayed during teaching practice in different schools. Appropriate knowledge of the subjects, differentiated teaching methods and skills are needed by pre-service teachers, to show their readiness to teach and make an impact on the teaching profession. The teaching practice is the practical field of practice for pre-service teachers to be exposed to the basic foundations of the teaching profession. Findings indicated that subject mentors are tasked with the provision of support, mentoring and guidance to the PGCE students while on teaching practice. Assessments of these PGCE students by their subject mentors affirmed their readiness to teach, as well as readiness and willingness to be mentored. While subject mentors were also determined to provide support to these PGCE students. The mentors identified some lapses in their mentees, which they encouraged them to improve upon. Conclusively, the PGCE students were willing to learn from their mentors for their professionalism in the school system.

\section{Recommendations}

Training professionals in teacher education is the main purpose of teaching practice. It provides an avenue for pre-service teachers to be exposed to real situations within the school system. This study therefore recommends:

- There is a need for pre-service teachers to be developed on how to use, create and integrate LTSMs into their lesson delivery. The lecturers and the subject mentors should encourage, train and develop pre-service teachers' creativity to create and use various LTSMs for classroom practices.

- Subject mentors should be regularly hosted by the partner-universities to educate them on their responsibilities to pre-service teachers. The training will empower subject mentors to adequately support pre-service teachers, provide them with the universities' expectations from them.

- Regular monitoring of mentor-mentee relationship by the university authorities. The university system should be effective in monitoring the relationship between mentors and their mentees. Comprehensive reports should be provided by the mentors on the pre-service teachers after the teaching practice to the university's teaching practice department. The university authorities should also follow-up on all activities of the students while on teaching practice. Defaulting students should be made to repeat teaching practice.

- Schools should be encouraged to provide the necessary support to the students, while all forms of indiscipline from students on teaching practice should not be condoned or covered up by the mentors or schools. Teaching is a noble profession, and sanity should be promoted.

- Mentors should not relinquish their classes or lessons to students on teaching practice as relief teachers. The practice where mentors abandon their responsibilities to students on teaching practice as a form of temporary leave or relief from classroom practice should be discouraged. Pre-teachers should always accompany mentors to classes for lesson observation, while mentors are also advised to observe mentees' classes for improvement support.

\section{Limitations}

This study was limited to only 5 subject mentors from five different schools in KwaZulu-Natal province. Hence, findings of this study cannot be generalized for the whole province or country. The authors recommend for a comprehensive study that will involve more subject mentors from many schools and many provinces of South Africa. These will provide the stakeholders with more information on the phenomenon. 


\section{REFERENCES}

[1] Ajani, O. A. "Understanding teachers as adult learners in professional development activities for enhanced classroom practices". African Journal of Development Studies, vol. 9, no. 2, pp.195-208, 2019, https://doi.org/10.31920/2075-653 4/2019/9n2a10.

[2] Ajani, O. A., "Teachers' professional development in South African high schools: how well does it suit their professional needs?" African Journal of Development Studies (formerly AFFRIKA Journal of Politics, Economics and Society), vol.10, no. 3, pp. 59-79, 2020, https://doi.org/10.31920/263 $4-3649 / 2020 / 10 n 3 a 4$.

[3] Ajani, O. A., S. Govender, "Teachers' perspectives on in-service professional development in South African and Nigerian high schools", Gender \& Behaviour, vol. 17, no. 2, 13146-13160, 2019.

[4] Ali, S., M.I. Khalid, "Assessment of teaching practice: Perceptions of pupil teachers towards supervisors and cooperating teacher's practices", The Dialogue, vol. 10, no. 4, pp.424-434, 2015.

[5] Braun, V., V. Clarke, "Using thematic analysis in psychology", Qualitative research in psychology, vol. 3, no.2, pp. 77-101, 2006.https://doi.org/10.1191/1478088706qp063 oa

[6] Chiatula, V. O., Integrative pre-service elementary teacher training: The role of interdisciplinary collaborative mathematics", Education, vol. 136, no. 2, pp. 113-122, 2015.

[7] Christie, F., Conlon, T., Gemmell, T., A. Long, "Effective partnership? Perceptions of PGCE student teacher supervision", European Journal of Teacher Education, vol. 21, no. 2, pp. 109-123, 2004, https://doi.org/10.1080/026197 6042000222999.

[8] Christiansen, I., Bertram, C., S. Land, "Understanding Research". Pietermaritzburg: UKZN Faculty of Education, 2010.

[9] Cohen, L., Manion, L., K. Morrison, "Research Methods in Education ( $7^{\text {th }}$ ed.). London: Routledge, 2013, https:// doi.org/10.4324/9780203720967.

[10] Creswell, J. W., C.N. Poth, "Qualitative Inquiry and Research Design: Choosing Among Five Approaches", Thousand Oaks: Sage, 2017.

[11] Davies, J. P., N. Pachler, "Teaching and learning in higher education: Perspectives from UCL", London: UCL IOE Press, 2018.

[12] Dewey, J. "How we think: A restatement of the relation of reflective thinking to the educative process", Chicago, IL: Henry Regnery, 1933.

[13] Ed Batista,www.edbatista.typepad.com/edbatista/images/20 07/10/Experiential_Learning_Cycles_696.jpg, (accessed Jan1, 2013).

[14] Endeley, M. N., "Teaching Practice in Cameroon: The effectiveness of the University of Buea model and implications for quality", Australian Journal of Teacher
Education, vol. 39, no. 11, pp. 147-160, 2014. https://doi.org/10.14221/ajte.2014v39n11.9

[15] Girvan, C., Conneely, C., B. Tangney, "Extending experiential learning in teacher professional development", Teaching and Teacher Education, vol. 58, pp.129-139, 2016. https://doi.org/10.1016/j.tate.2016.04.009

[16] Guillen, L., K. Zeichner, "A university-community partnership in teacher education from the perspectives of community-based teacher educators. J. Teach. Educ. vol.69, pp. 140-153, 2018, DOI: 10.1177/0022487117751133.

[17] Haigh, M., Ell, F., V. Mackisack, V. "Judging teacher candidates' readiness to teach", Teaching and Teacher Education, vol. 34, pp. 1-11, 2013. https://doi.org/10.1016/j. tate.2013.03.002.

[18] Hallman, H. L., T.L. Rodriguez, "Fostering community-based field experiences in teacher education," in Rethinking Field Experiences in Preservice Teacher Preparation: Meeting New Challenges for Accountability, (ed) E. R. Hollins, New York, NY: Routledge, pp. 99-116, 2015. doi: 10.4324/9781315795065.

[19] Heeneman, S., W. de Grave, W. (2019). Development and initial validation of a dual-purpose questionnaire capturing mentors' and mentees' perceptions and expectations of the mentoring. BMC Med Education, vol. I9, no. 1, pp. 133, 2019. doi: 10.1186/s12909-019-1574-2.

[20] Heeralal, P. J. H., "Mentoring needs of pre-service teachers during teaching practice: A case study at a South African university", Journal of Educational and Social Research, vol. 4, no. 1, pp. 511-516, 2014.https://doi.org/10.5901/jesr.2014 .v4n1p511.

[21] Jackson, S., "Getting teachers learner-ready: Reforming teacher preparation", The Hunt Institute's, vol. 4, no. 4, pp.1-12, 2014.

[22] Kolb, D. A.. "Experiential Learning", Englewood Cliffs, NJ Prentice Hall, pp.136-141, 1984.

[23] Korkut, P., "Classroom Management in Pre-service Teachers' Teaching Practice Demo Lessons: A Comparison to Actual Lessons by In-service English Teachers", Journal of Education and Training Studies, vol. 5, no. 4, pp. 1-17, 2017, https://doi.org/10.11114/jets.v5i4.2164.

[24] Kiggundu, E., S. Nayimuli, "Teaching Practice: A make or break phase for student teachers", South African Journal of Education, vol. 29, no. 8, pp. 345-358, 2009, https://doi.org/10.15700/saje.v29n3a129.

[25] Maphalala, M. C., "Understanding the role of mentor teachers during teaching practice session." International Journal of Education Sciences, vol. 5, no. 2, pp. 123-130, $2013 \mathrm{https}: / /$ doi.org/10.1080/09751122.2013.11890069.

[26] Mekeredzi, T. G., D. Sibanda, "Part-time Post Graduate Certificate in Education teacher-students: What do they bring to and expect from a formal South African teaching programme? Australian Journal of Teacher Education, vol. 41, no.9, pp. 81, 2016, http://dx.doi.org/10.14221/ajte.2016v $4 \ln 9.5$.

[27] Mkhasibe, R. G., 'Evaluation of pre-service teachers' readiness to teach: A case study of a South African university". Doctoral thesis, Faculty of Education, University 
of Zululand, KwaDlangezwa, 2018.

[28] Mkhasibe, R. G., Maphalala, M.C., D.R. Nzima, "Perceptions of subject mentors on pre-service teachers' readiness to teach Economics and Management Sciences", Journal of Gender, Information and Development in Africa (JIGDA), vol. 7, no. 2, pp. 241-259, 2018, https://doi.org/10.31920/2050-4284/2018/v7n2a12.

[29] Mkhasibe, R. G., S. Olaniran, "Subject mentors' capabilities when mentoring student teachers during teaching practice", Gender and Behaviour, vol. 17, no. 2, pp. 14180-14187,2019.

[30] Moosa, M., L. Rembach, "Voices from the classroom: Pre-service teachers' interactions with supervising teachers", 2018, https://doi.org/10.18820/2519593X/pie.v36i1.1.

[31] Mukeredzi, T.G., Mthiyane, N., C. Bertram, "Becoming professionally qualified: The school-based mentoring experiences of part-time PGCE students", South African Journal of Education,vol. 35, no. 2, pp. 1-9, 2015.https://doi.org/10.15700/saje.v35n2a1057

[32] Nwanekezi, A. U., Okoli, N. J., S.A. Mezieobi "The attitude of student-teachers towards practice teaching at the University of Port Harcourt, Rivers State", Journal of Emerging Trends Educational Research and Policy Studies, vol. 2, no.1, pp. 41-46, 2011.

[33] Ojo, O. A., Adu, K. O., E.O. Adu, "School Experience: Institutions' Expectations from Pre-service Teachers", The Anthropologist, vol. 29, no. 1, pp. 19-26, 2017. https://doi.org/10.1080/09720073.2017.1335825
[34] Sepadi, M. D., "Student teachers' preparation for inclusive education: the case of the University of Limpopo", (Doctoral dissertation), 2018.

[35] Schatz-Oppenheimer, O., "Being a mentor: novice teachers' mentors' conceptions of mentoring prior to training. Professional development in education", vol. 43, no. 2, pp. 274-292, 2017.https://doi.org/10.1080/19415257.2016.1152 591

[36] Singh, P., C.C. Mahomed, "The value of mentoring to develop student teachers' work-integrated learning skills", International Business and Economics Research Journal vol. 12, no.11, pp. 1373-1388, 2013.https://doi.org/10.19030/ibe r.v12i11.8175

[37] Smit, T., "Self-regulated professionalism: a Whole Brain ${ }^{\circledR}$ Participatory Action Research design in a pre-service teacher mentoring context", (Doctoral dissertation, University of Pretoria, 2020.

[38] Taylor, Z. W., V.G. Black, "Talking to the mentees: Exploring mentee dispositions prior to the mentoring relationship", International Journal of Mentoring and Coaching in Education, vol. 7, no. 4, pp. 296-311, 2018. https://doi.org/10.1108/IJMCE-04-2018-0019

[39] Vesterinen, O., Toom, A., L. Krokfors, "From action to understanding: Student teachers' learning and practical reasoning during teaching practice", Reflective Practice, vol. 15, no. 5, pp.618-633, 2014. https://doi.org/10.1080/146239 43.2014.900028 